\title{
APPLICATION OF X-RAY COMPUTED TOMOGRAPHY IN THE EVALUATION OF SOIL POROSITY IN SOIL MANAGEMENT SYSTEMS
}

\author{
JOSÉ M. G. BERALDO ${ }^{1}$, FRANCISCO DE A. SCANNAVINO JUNIOR ${ }^{2}$, \\ PAULO E. CRUVINEL ${ }^{3}$
}

\begin{abstract}
The study aimed to evaluate a methodology to quantify the porosity of the soil using computed tomography in areas under no-tillage, conventional tillage and native forest. Three soil management systems were selected for the study: forest, conventional tillage and no-tillage. In each soil management system, undisturbed soil samples were collected in the surface layer $(0.0$ to 0.10 $\mathrm{m})$. The tomographic images were obtained using a X-ray microtomography. After obtaining the images, they were processed, and a methodology was evaluated for image conversion into numerical values. The statistical method which provided the greatest accuracy was the percentile method. The methodology used to analyze the tomographic image allowed quantifying the porosity of the soil under different soil management. The method enabled the characterization of soil porosity in a non-evasive and non-destructive way.
\end{abstract}

KEYWORDS: precision farming, image processing, X-ray microtomography, macroporosity.

\section{APLICAÇÃO DA TOMOGRAFIA COMPUTADORIZADA DE RAIOS X NA AVALIAÇÃO DA POROSIDADE DO SOLO EM SISTEMAS DE MANEJO DO SOLO}

RESUMO: O estudo teve por objetivo avaliar uma metodologia para quantificar a porosidade do solo, utilizando a tomografia computadorizada, em áreas sob sistema de semeadura direta, preparo convencional e mata nativa. Três sistemas de manejo do solo foram selecionados para o estudo: mata, preparo convencional e semeadura direta. Em cada sistema de manejo do solo, foram coletadas amostras indeformadas de solo na camada superficial $(0.0-0.10 \mathrm{~m})$. As imagens tomográficas foram obtidas utilizando um sistema de microtomografia de raios-X. Após a obtenção das imagens, estas foram processadas, e uma metodologia foi avaliada para conversão da imagem em valores numéricos. O método estatístico que proporcionou maior exatidão foi o método do percentil. A metodologia utilizada para analisar a imagem tomográfica permitiu quantificar a porosidade do solo em diferentes condições de manejo de solo. O método viabilizou a caracterização da porosidade do solo de forma não evasiva e não destrutiva.

PALAVRAS-CHAVE: agricultura de precisão, processamento de imagens, microtomografia de raios-X, macroporosidade.

\section{INTRODUCTION}

Soil porosity refers to the volume of soil pores occupied by air and/or by water. The soil particles have different arrangement and structure, varying, thus, the form (ELLIOT et al., 2010; PAPADOPOULOS et al., 2009), the length (WANG et al., 2012), the width and the tortuosity (UDAWATTA et al., 2008). Therefore, the arrangement of the soil particles determines the quantity of existing pores.

\footnotetext{
${ }^{1}$ Doutor em Agronomia, Instituto Federal de Educação, Ciência e Tecnologia de São Paulo / Pós-Doutorando na Embrapa Instrumentação, São Carlos-SP, Fone: (16) 2107-2826, jmgberaldo@ifsp.edu.br

${ }^{2}$ Doutor em Física Computacional, Instituto de Física de São Carlos (USP) / Embrapa Instrumentação, São Carlos-

SP, scannavino@usp.br

${ }^{3}$ Doutor em Automação, Embrapa Instrumentação, São Carlos-SP, Fone: (16) 2107-2826, paulo.cruvinel@embrapa.br

Recebido pelo Conselho Editorial em: 15-5-2013

Aprovado pelo Conselho Editorial em: 08-7-2014
} 
The soil pores vary in size and shape and are interconnected. BOUMA (1982) highlights the importance of the continuity of the pore network for the flow of water in soil, and small pores may lead to better water conduction since that they form a continuous network, while larger pores may not contribute to the flow, if they present a discontinuity. Thus, is not only the pore diameter, but also their continuity, which interferes in the process of redistribution of soil water.

It is important to assess the porosity of the soil, because, depending on the soil management adopted, restriction of soil water flow may occur, thus compromising the plant growth.

To determine the soil porosity, volumetric measurements are conventionally used. For this, it is necessary to collect undisturbed soil samples for quantitative evaluation of porosity. However, according to KUBIENA (1970), the continuity, size and shapes of the pores may be visualized microscopically.

A methodology which allows us to observe the structural components of the soil, allowing better visualization of the behavior of the structure and soil porous space, is the computed tomography.

Computed tomography (CT) is a technique that was developed with the objective of obtaining the image of the axial cross-section of an object. After obtaining the images, it is possible to store data in a two-dimensional matrix (2D) (CRUVINEL \& BALOGUN, 2006).

Nowadays, advanced techniques of image processing allow to quantify the pore volume and to represent the object in three dimensions (PETH et al., 2008; TAINA et al., 2008).

In comparison with classical methods used in soil science, computed tomography has the following advantages: it is a non-evasive and non-destructive technique; allows measuring the heterogeneity in the soil and where it occurs; allows measuring soil density and water content at a high resolution; it is possible to obtain images of soil samples in two and three dimensions independent of the geometry and shape of each sample (CRUVINEL et al., 2009; PIRES et al., 2010).

One of the stages in image processing consists of image conversion into numerical values, so the image may be subdivided into a grid containing several pixels, which are used as a unit of measure for describing the geometric dimension. Nowadays, the process for separation or definition of the threshold which distinguishes solid pores of the image is performed by visual inspection, empirically, and may cause errors.

The objective of this study was to apply image processing techniques to quantify and obtain the necessary information to characterize the pore space under different conditions of soil management.

\section{MATERIAL AND METHODS}

The soil under study belongs to Oxisols, which are the most representative soil units of Brazil. The soil of the experimental area is an Eutrophic Red Latosol, clay texture, moderate A, kaolinitic, hipoferric and smooth wavy relief.

Three soil management systems were selected for the study: (a) Forest - characterized by forest, in which the soil has not suffered any type of management; (b) Conventional tillage deforested area and usually cultivated with annual crops (soybeans and maize), characterized by soil tillage, consisted of chiseling and harrowing for soil leveling, (c) No-tillage - area cultivated for 6 years with two annual crops, soybeans in the summer and maize in the winter in no-tillage system (Figure 1). The soil physical properties are shown in Table 1. 


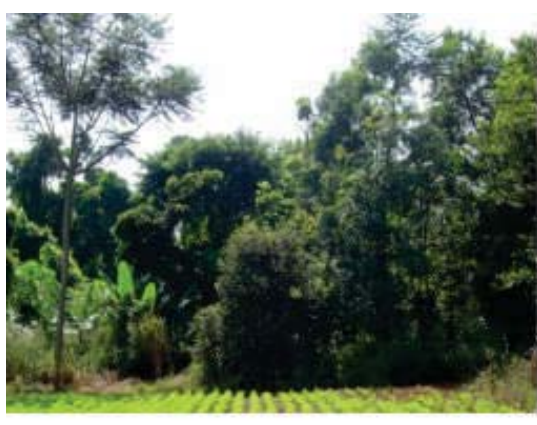

(a) Native forest

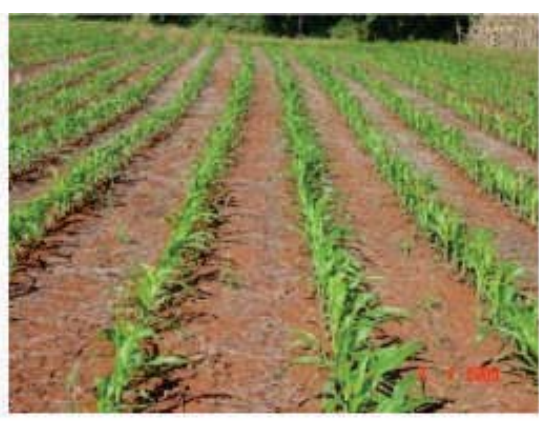

(b) Conventional tillage

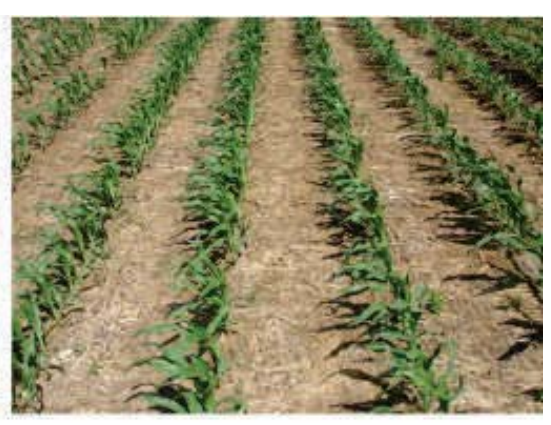

(c) No-tillage system

FIGURE 1. Soil management systems in the experimental area under native forest (a), conventional tillage (b) and no-tillage system (c).

TABLE 1. Mean values for granulometric analysis, bulk density (BD), total porosity (Pt), macroporosity (Ma) and microporosity (Mi) of the soil layer from 0.0 to $0.10 \mathrm{~m}$.

\begin{tabular}{|c|c|c|c|c|c|c|c|}
\hline Management systems & Clay & Silt & Sand & $\mathrm{BD}$ & $\mathrm{Pt}$ & Ma & Mi \\
\hline & \multicolumn{3}{|c|}{---------g kg ${ }^{-1}$--------- } & $\mathrm{Mg} \mathrm{m}^{-3}$ & \multicolumn{3}{|c|}{ 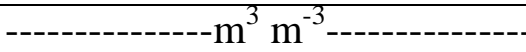 } \\
\hline No-tillage & 470 & 28 & 502 & 1.63 & 0.35 & 0.03 & 0.32 \\
\hline Conventional tillage & 462 & 42 & 496 & 1.49 & 0.42 & 0.05 & 0.37 \\
\hline Native Forest & 631 & 124 & 245 & 0.80 & 0.64 & 0.34 & 0.30 \\
\hline
\end{tabular}

Undisturbed soil samples were collected in the soil surface layer (0.0 to $0.10 \mathrm{~m})$ using PVC cylinders, with beveled edge, $6.4 \mathrm{~cm}$ high, $3.7 \mathrm{~cm}$ of inner diameter and approximate volume of $68.8 \mathrm{~cm}^{3}$. After sampling the excess of soil in the upper and lower part of the cylinder were removed.

After sampling, the undisturbed soil samples were taken to the Laboratory of Nuclear Techniques "Silvio Crestana" at Embrapa Instrumentation located in São Carlos - state of São Paulo (SP), Brazil.

The tomographic images were obtained using a system of X-ray microtomography, Model 1172 of SkyScan, composed of a tube of microfocus X-rays with a high voltage source $(100 \mathrm{kV})$, a sample holder with precision manipulator and a detector based on a CCD camera of 10MP (4000 x 2300 pixels) connected to a computer for control and acquisition of the images.

The acquisition of tomographic images (cross-sections) was performed in two stages. The first one was the acquisition of images in various angular projections of the sample along a rotation of $180^{\circ}$ and $360^{\circ}$ with very accurate rotational steps, and the second one consisted in the reconstruction of images of cross-sections from the images of the angled projections through the Feldkamp conebeam volumetric reconstruction algorithm. The images were obtained with a resolution of 34.81 $\mu \mathrm{m}$. This resolution allows identification of macroporosity (pore diameter greater than $0.05 \mathrm{~mm}$ ) and a small strip of micropores (pores having diameter less than $0.05 \mathrm{~mm}$ ).

A film composed by aluminum and copper was used to obtain images, which allowed changing the camera sensitivity to polychromatic radiation from the source of X-rays, in order to reduce the effect called beam hardening.

From the undisturbed soil sample collected in the field (Va), several slices (planes) of the cross-sections were taken.

It was defined a region of interest for analysis due to the large number of images. The central portion of the sample was chosen to be analyzed, because it consist a region where no disturbances occur in the sample (Figure 2). 
Maintaining the ratio between the height and the diameter of the cylinder close to one, this volume $(\mathrm{Vb})$ was $39.7 \mathrm{~cm}^{3}$. To avoid disturbances near the cylinder wall, the same proportion of the volume calculated in $\mathrm{Va}$ for $\mathrm{Vb}$ was maintained, and was obtained the volume of the central portion of the sample (Vc) of $22.9 \mathrm{~cm}^{3}$.
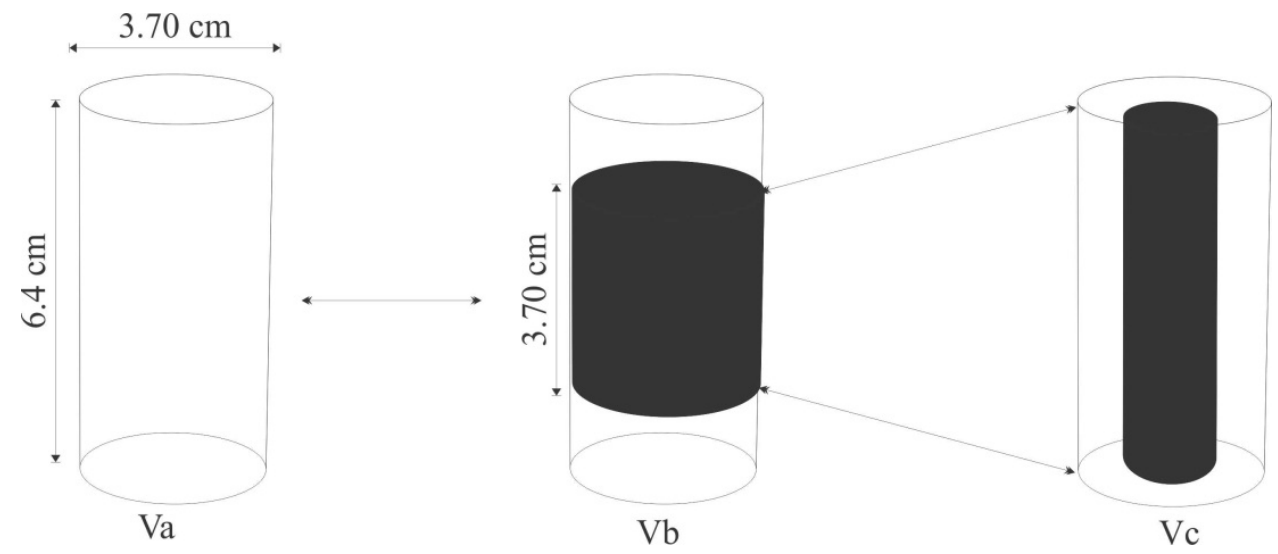

FIGURE 2. Schematic diagram in the area of interest for analysis with X-ray microtomography.

From this volume $(\mathrm{Vc})$, it was calculated the number of slices containing in it (Figure 2), and thus it was possible to calculate the volume of each slice $(\mathrm{Vd})$.

Knowing the volume of a voxel, which corresponds to the least amount of information that an image can have per unit of volume, it can be determined the total number of voxels of a slice. And thus, it can be calculated the required area representing that volume, i.e., the size of the matrix to be analyzed.

In the present study, the size of the analyzed image was $700 \times 700$ pixels, for a total of 49000.00 pixels. Eleven slices (images) were selected of the central portion of the sample (Vc), spaced vertically at regular intervals, totaling eleven replicates for each handling.

The tomographic images (cross-sections) were recorded in BMP (Windows ${ }^{\circledR}$ Bitmap) (Figure 4). After obtaining the images, those were processed using the computer system MATLAB (MATLAB, Version 7.9.0, 2009).

A routine was developed to enable the reading of the images, which had 256 gray levels, and so it was possible to convert the image into a data matrix.

To convert the image into numerical values, the image was subdivided into a grid containing several pixels, which are used as a unit of measure for describing the geometric dimension of the image. Each pixel carries information about the color or the gray level it represents.

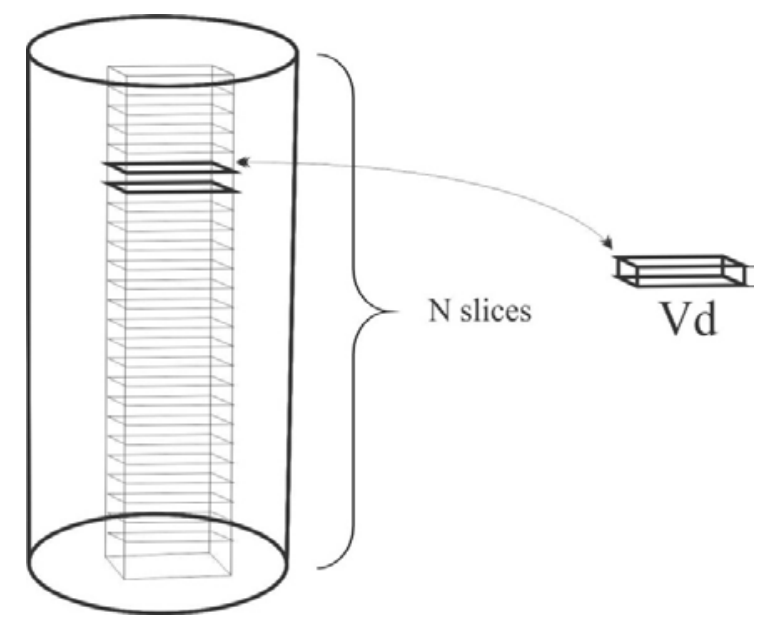

FIGURE 3. Slices or plans of the central position of the sample. 
(a)

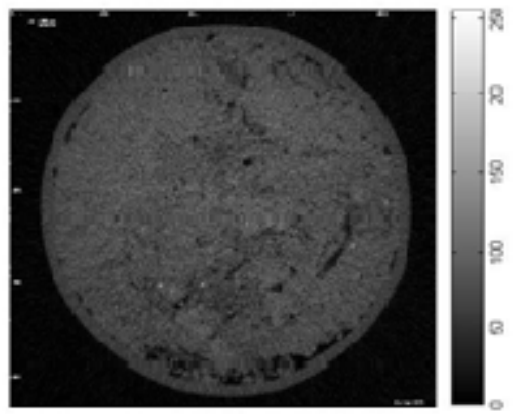

(b)

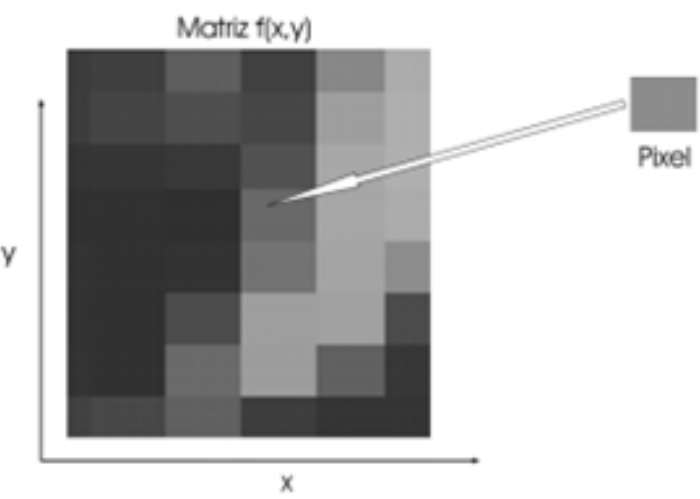

FIGURE 4. Example of a tomographic image (a) and data matrix containing the gray levels that the image represents (b)

One way to observe the distribution of gray levels of the image is through the histogram (Figure 5). In the gray scale, black is represented by the value 0 (pore) and white by 255 (solid). Thus each image provides a specific tone composition, depending on the attenuation coefficient of each particle of the soil.

To validate the proposed methodology, it was used a Phantom for the physical characterization of a pattern in order to validate a threshold for separating pores and solids. Phantom refers to a test body constructed with known or reference parameters used for calibration or characterization of patterns.

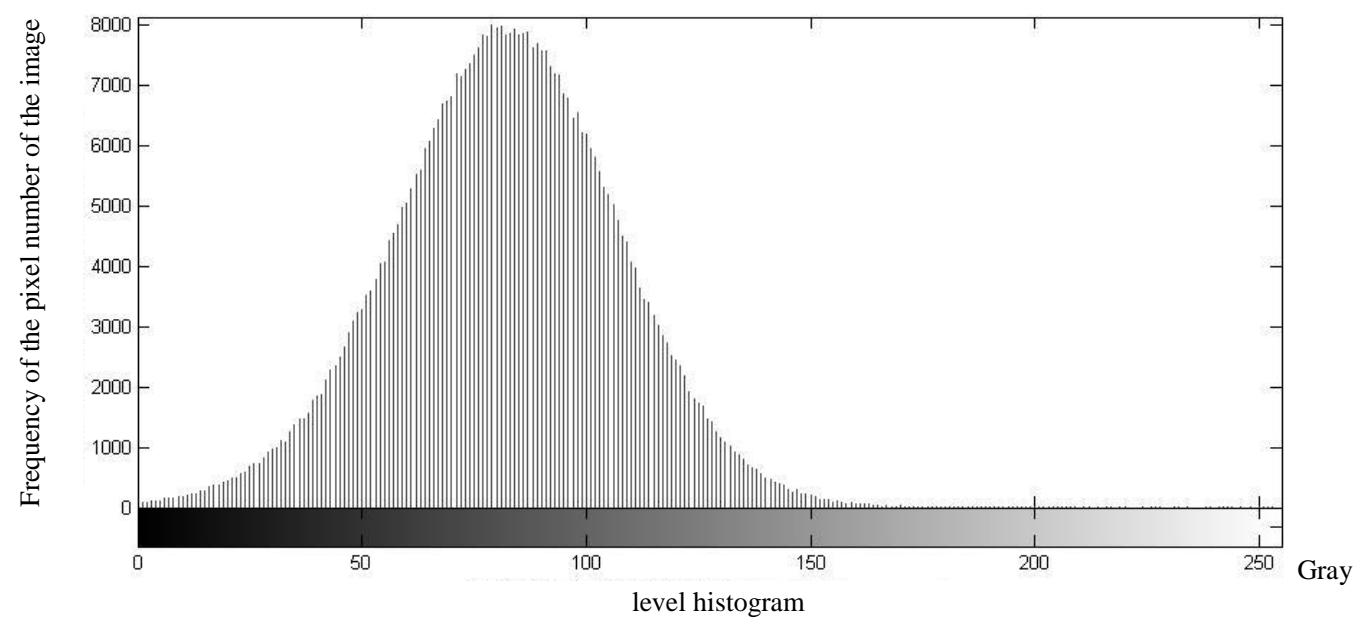

FIGURE 5. Gray level histogram of the image obtained in the plot cultivated under no-tillage.

The same methodology used for analyzing tomographic images of the soil was performed to analyze the Phantom (Figure 6). 

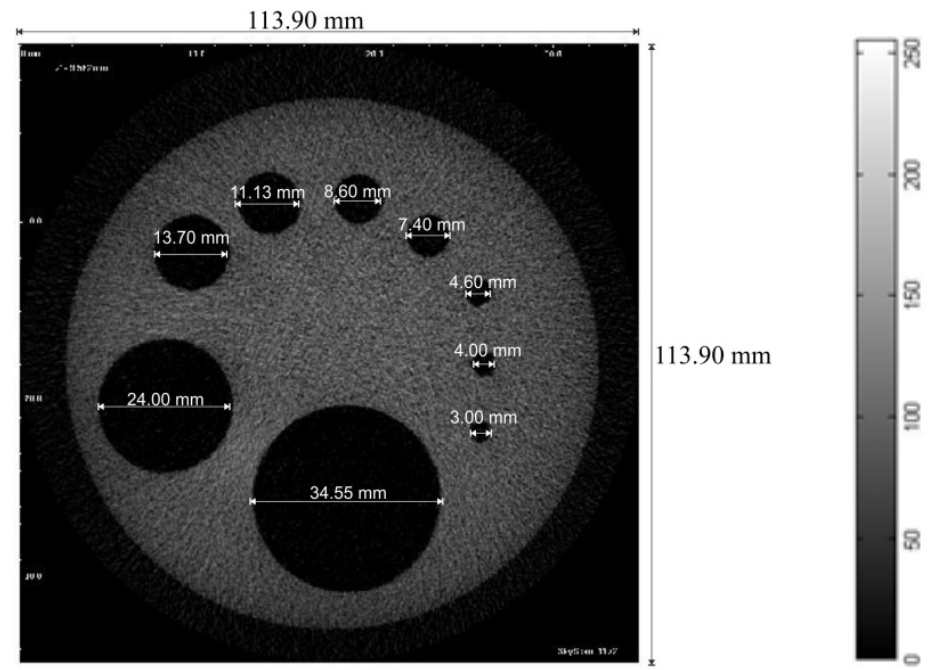

FIGURE 6. Tomographic image of the Phantom.

It is observed that the tomographic image showed many noises (Figure 6). Within the largest circumference, there is nine spheres not filled by solid material that presented noises, and near the edge of the largest circumference there are many noises.

Several techniques were used in the study of image processing, aiming to improve the image and obtain the information necessary for its characterization. Analysis techniques were based on mathematical morphology. Mathematical morphology is a tool used to extract image components that are useful in the representation and description of the shape of a region.

The first step of the analysis of the Phantom consisted in lightening the image in order to delineate the edge of the larger circle. From Figure 6, ten tomographic images were superimposed and its resulting image is shown in Figure 7.

It is noted that the first image (Figure 6) is sharper than the second (Figure 7). This shows that the simple image overlay, without the adoption of appropriate criteria, is not enough to improve the final image quality, and may even worsen it. However, in this study it was aimed to highlight the edge of the image, a result in which the criteria used was efficient.

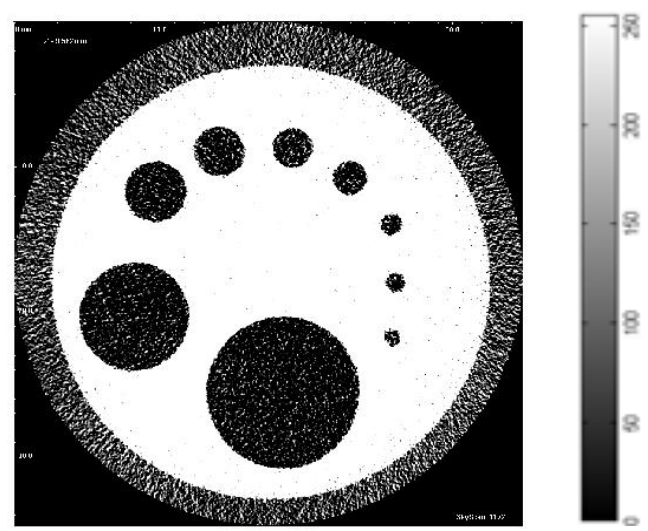

FIGURE 7. Image generated after the overlay of the tomographic image.

The second step of the analysis was to change the shape of the structuring element. It was selected the disc shape (Figure 8), for presenting a circular shape. 


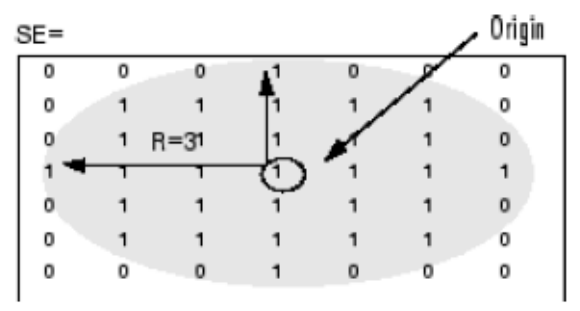

FIGURE 8. Example of the selected disc shape.

It was tested different radii 1, 2, 3, 4, 5, 6, 8 and 10, where the radius is a non-negative integer number (Figure 9). The radius which produced less noise was $\mathrm{R}=4$ (Figure 9).

After defining the shape and size of the structuring element, it was performed the morphological operations of opening and closing. The opening is a morphological operation that generally smoothes the contour of an image, breaks narrow isthmuses and eliminates thin protrusions. The closing operation will fill or close the voids, removing many of the white noise pixels.

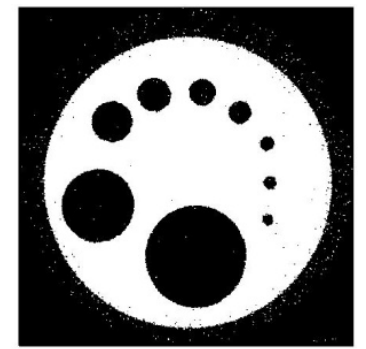

$\mathrm{R}=1$

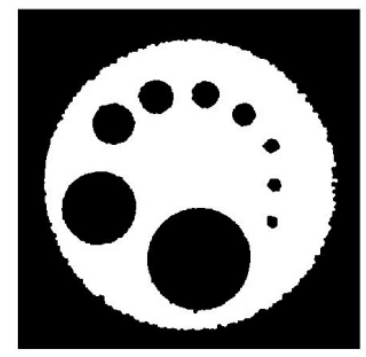

$\mathrm{R}=5$

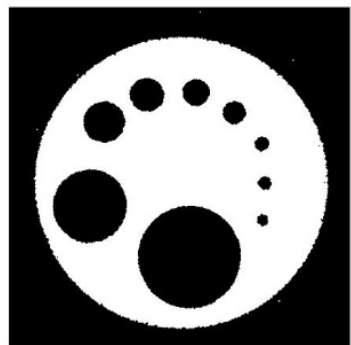

$\mathrm{R}=2$

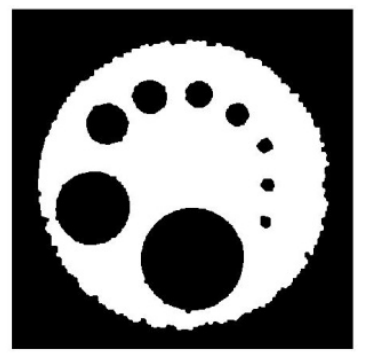

$\mathrm{R}=6$

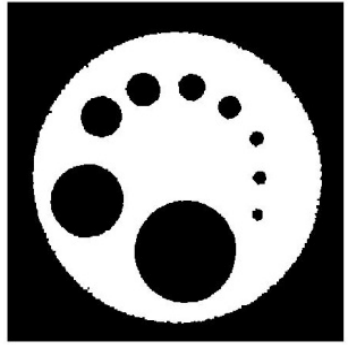

$\mathrm{R}=3$

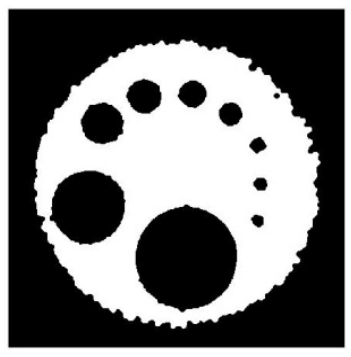

$\mathrm{R}=8$

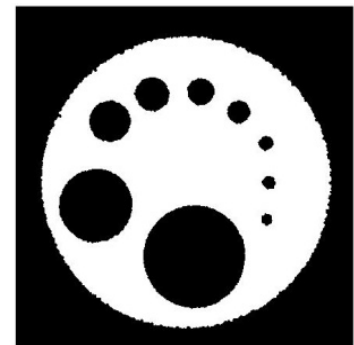

$\mathrm{R}=4$

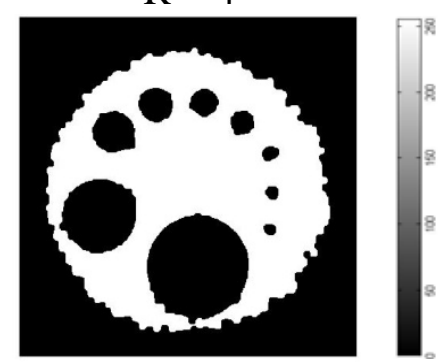

$\mathrm{R}=10$

FIGURE 9. Change of the structuring element in the disc shape, radius 1, 2, 3, 4, 5, 6, 8 and 10.

The third step of the analysis involved the localization of a reference point for separating the image background of the object of investigation. 

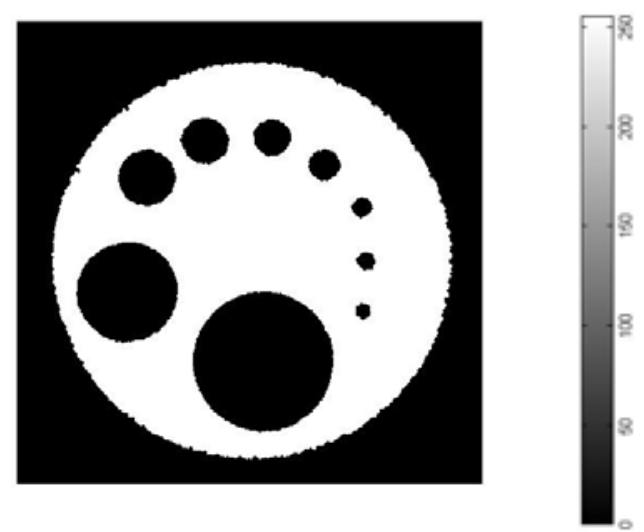

FIGURE 10. Image generated after setting the element in the disk shape and in the operation of opening and closing.

The method used is based on calculating the Euclidean distance (De), given by:

$$
\operatorname{De}(i, j)=\sqrt{\left(i_{2}-i_{1}\right)^{2}+\left(j_{2}-j_{1}\right)^{2}}
$$

in which,

$i_{1}$ and $j_{1}$ - represent the coordinates of the pixel p, and

$i_{2}$ and $j_{2}$ - represent the coordinates of the pixel $q$.

The Euclidean distance is a procedure that allows calculating the distance of a pixel of the nearest pixel background belonging to an object within the image, from an image containing the object (or its contour).

To highlight the visualization, the image background was modified to a shade of gray (Figure 11). From the processed image and without noise, it was possible to count the pixels number of the Phantom (Table 2).
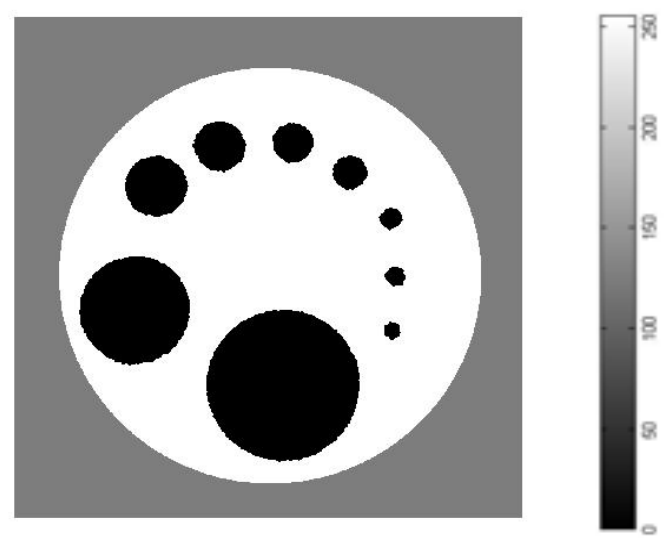

FIGURE 11. Image obtained after setting the tone from the background. 
TABLE 2. Counting of the pixels number of the Phantom.

\begin{tabular}{ccc}
\hline Tone & Pixels Number & Percentage (\%) \\
\hline White (255) & 401.605 & 74.24 \\
Black (0) & 139.372 & 25.76 \\
\hline Total & 540.977 & 100 \\
\hline
\end{tabular}

In this study, it was adopted three methodologies to define thresholding $(\mathrm{T})$ in the original tomographic image. The first methodology consisted in taking 5\% of error in the range of gray levels present in the image, called "Method with 5\% Error."

In the second methodology, it was used the separatrix measurement called the percentile. This statistic is based on the calculation of percentiles of the frequency distribution of the image histogram (Figure 12). It was adopted the value of the first percentile calculated of 2.5\%.

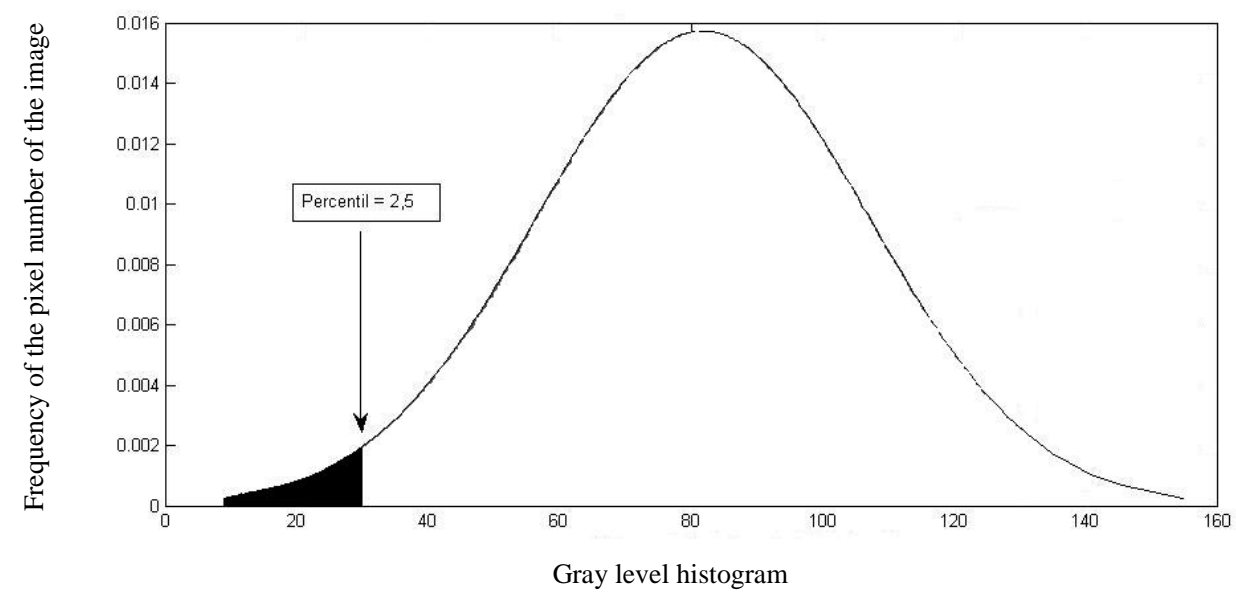

FIGURE 12. Normalized histogram of the gray levels of the sample and an indication of the value of $2.5 \%$ percentile.

The third methodology used was Otsu's bimodal thresholding method (OTSU, 1979). It is a method that seeks to automatically select the limits of the gray levels that best separate or segment the elements of interest in an image of an specific class, with the selection criteria of minimizing the intra-group variance.

With the separation of the value that is considered pore or solid, the images were binarized. The binarization was done sweeping up the image, pixel by pixel, and applying Equation 2:

$$
g(x, y)=\left\{\begin{array}{l}
0, \text { se } f(\mathrm{x}, \mathrm{y}) \leq T \\
1, \text { se } f(\mathrm{x}, \mathrm{y})>T
\end{array}\right.
$$

in which,

$$
\begin{aligned}
& f(\mathrm{x}, \mathrm{y}) \text { - is the tomographic image, and } \\
& \mathrm{g}(\mathrm{x}, \mathrm{y}) \text { - is the binarized image. }
\end{aligned}
$$

The conversion of the image with gray levels to binary representation is important to perform the calculation of the percentages of pores and solids present in the image. To this, it was accounted in the matrix, all values with value 0 (pore) and value 1 (solid) of the image.

After the definition of the thresholding, it was applied the percentile method in eleven images selected of the central portion of the undisturbed soil sample in the three soil management systems evaluated. 


\section{RESULTS AND DISCUSSION}

The thresholding methods showed distinct results (Table 3). The percentile method was the one which presented results closer to the reference. The method with $5 \%$ error overestimated the solid values of the image, while Otsu's method underestimated the values.

It is observed in the image (Figure 13) that by the method with 5\% error many noises were generated inside the smaller circles. As for Otsu's method, opposite result was obtained, with the noise prevailing inside the largest circle.

The method which provided greater accuracy was the percentile method, whose value of thresholding was intermediate $(T=20)$ to the other methods.

PETH et al. (2008) mentioned that the quality of segmentation is a key determinant for the quality of pore statistics derived from computed tomography images.

There are various studies dealing with the problem of image segmentation in soils and one conclusion that can be drawn from them is that a simple straightforward best segmentation method is currently not available, and the selection of an appropriate procedure depends very much on image quality, resolution, frequency distribution of attenuation values, and finally the focus of the study (PAGENKEMPER et al., 2013).

TAINA et al. (2008) argued the perfect discriminations of soil phases by simple thresholding may be difficult in some situations, due to attenuation and partial volume effects, especially when $\mathrm{X}$-ray computed tomography instruments with different performances are employed.

The values of the percentage of macropores and solids showed no difference between soil management under no-tillage and conventional tillage (Table 4). However, when compared with the results obtained in the forest area, there is an increase of 10 times in the amount of the percentage of soil pores.

TABLE 3. Counting values of the pixels number of the tomographic image of the Phantom after application of the thresholding methods.

\begin{tabular}{cccccc}
\hline \multirow{2}{*}{ Method } & \multicolumn{2}{c}{ Pixels number } & \multicolumn{2}{c}{ Percentage (\%) } & Percentage Error \\
\cline { 2 - 5 } & White $(255)$ & Black (0) & Solids & Pores & $\%$ \\
\hline 5\% error $(\mathrm{T}=9)$ & 418.371 & 122.606 & 77.34 & 22.66 & $+/-3.10$ \\
Percentile $(\mathrm{T}=20)$ & 405.738 & 135.239 & 75.00 & 25.00 & $+/-0.76$ \\
Otsu's $(\mathrm{T}=41)$ & 381.986 & 158.991 & 70.62 & 29.38 & $+/-3.62$ \\
\hline Reference (Phantom) & 401.605 & 139.372 & 74.24 & 25.76 & \\
\hline
\end{tabular}

VAZ et al (2011) showed that porosities derived from samples scanned at the lowest considered resolution $(30 \mu \mathrm{m})$ accounted for $<20 \%$ of the physically measured porosities for two Brazilian Oxisols. From these results it is evident that a spatial scanning resolution of a few microns is required to access a considerable portion of the total soil porosity that is composed of micro and macropores.

The macroporosity is an important aspect in root development and, consequently, the development of the plants. Macroporosity values must be at least $10 \%$ of the total volume of soil to allow gas exchanges and root growth of most upland crops (TAVARES FILHO et al., 2010).

There was a mean increase in soil macroporosity around $22 \%$ in the area under forest in relation to the area under no-tillage and conventional tillage (Table 4). These results confirm the rearrangement of soil particles promoted by tillage and conventional tillage.

PAPADOULOS et al. (2009) found differences in soil porosity when evaluating systems of conventional management and organic management, suggested that greater porosity and average 
pore size may have a positive effect on aggregate stability by allowing entrapped air to escape, reducing pressure build-up.

The soil porous space, assessed by tomographic and binarized images, was different for the soil management under conventional tillage and no-tillage in relation to forest area (Figure 14).

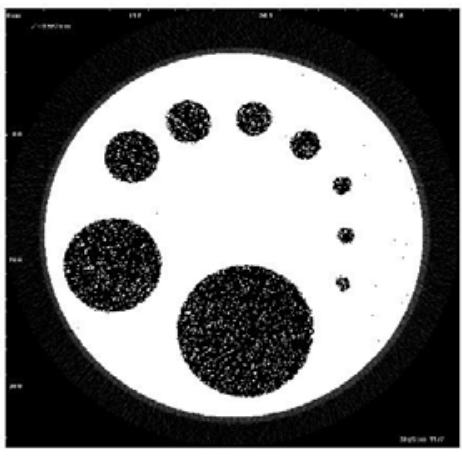

Method with 5\% Error

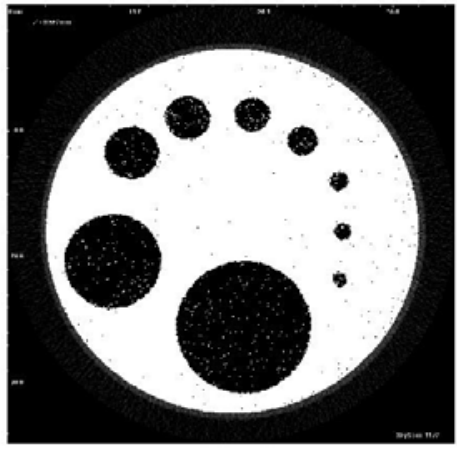

Percentile Method

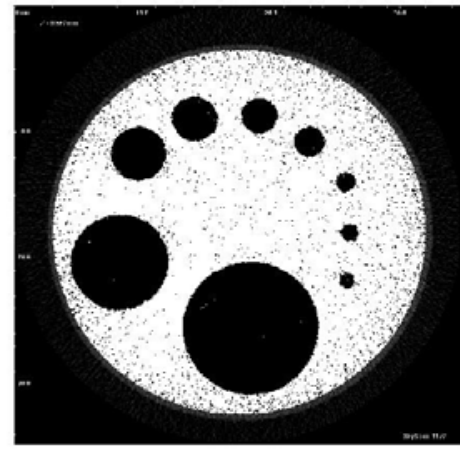

Otsu’s Method

FIGURE 13. Image obtained after the thresholding by the method with $5 \%$ error, the percentile method and the Otsu's method.

TABLE 4. Percentage of pores and solids of the soil using computed tomography in the soil management under no-tillage, conventional tillage and native forest.

\begin{tabular}{ccccccc}
\hline \multirow{2}{*}{ Image } & \multicolumn{2}{c}{ No-tillage } & \multicolumn{2}{c}{ Conventional tillage } & \multicolumn{2}{c}{ Forest } \\
\cline { 2 - 7 } & \% Macropores & \% Solids & \% Macropores & \% Solids & \% Macropores & \% Solids \\
\hline 1 & 2.4 & 97,6 & 2.4 & 97.6 & 24.5 & 75.5 \\
2 & 2.4 & 97.6 & 2.5 & 97.5 & 24.6 & 75.4 \\
3 & 2.4 & 97.6 & 2.4 & 97.6 & 24.7 & 75.3 \\
4 & 2.3 & 97.7 & 2.5 & 97.5 & 24.8 & 75.2 \\
5 & 2.3 & 97.7 & 2.4 & 97.6 & 24.8 & 75.2 \\
6 & 2.3 & 97.7 & 2.3 & 97.7 & 24.6 & 75.4 \\
7 & 2.3 & 97.7 & 2.4 & 97.6 & 24.0 & 76.0 \\
8 & 2.8 & 97.2 & 1.9 & 98.1 & 24.8 & 75.2 \\
9 & 2.3 & 97.7 & 2.4 & 97.6 & 24.3 & 75.7 \\
10 & 2.4 & 97.6 & 2.4 & 97.6 & 24.3 & 75.7 \\
11 & 2.3 & 97.7 & 2.5 & 97.5 & 24.4 & 75.6 \\
\hline Mean & 2.4 & 97.6 & 2.4 & 97.6 & 24.5 & 75.5 \\
\hline
\end{tabular}

In areas under cultivation (conventional tillage and no-tillage), there is predominance of micropores, which may be due to the large extension, branching and root activity. Grasses possess fasciculated roots which penetrate the soil, giving the shape of a large tangled, dense and voluminous.

According to PAGENKEMPER et al (2013) while roots, with the exception of root hairs, grow partially into transmission pores, in general with diameters larger than $50 \mathrm{~mm}$, they also penetrate the compressible soil growing along aggregates, building a functioning root network to explore the soil for water and nutrients. 
(a) No-tillage
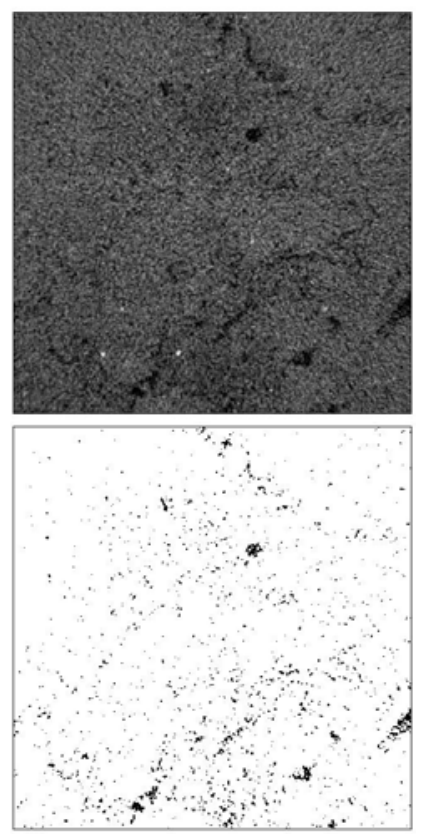

(b) Conventional Tillage
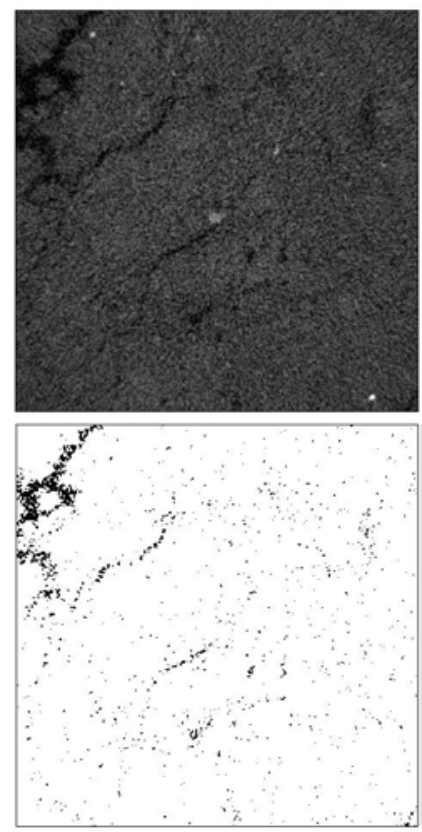

(c) Native Forest
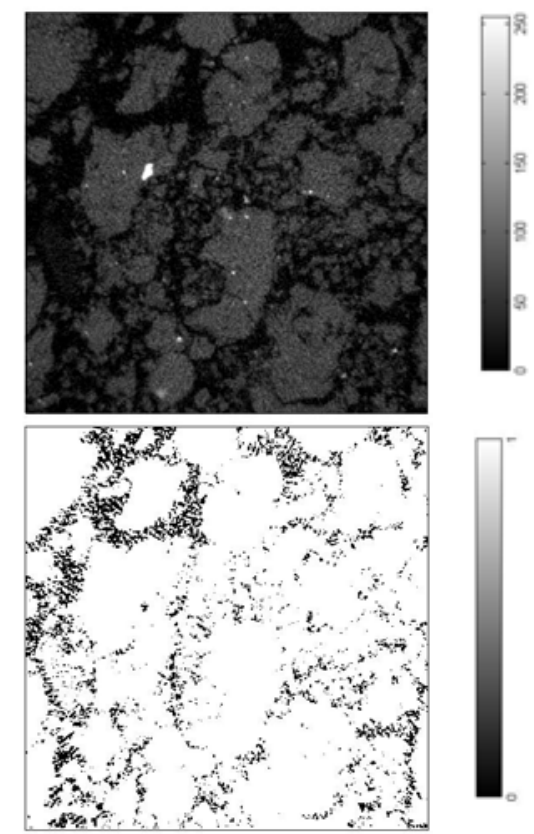

FIGURE 14. Tomographic image (above) and binarized image (below) under no-tillage (a), conventional tillage (b) and native forest (c).

When observing the tomographic and binarized image in the forest area, there is visually more presence of pores in the soil, and the image processing technique was useful for detecting variations in soil macroporosity and validated by the image. It is observed the presence of holes of different sizes and shapes in the forest area. This change in the soil structure affects water retention, influencing the dynamics of soil water. PERRET et al. (2000) discussed the importance of pore structure complexity in flow dynamics, and described macropore and matrix flow domain characteristics in soil.

It was found that the soil management changed the soil porosity, and that it was possible, through the methodology adopted, to verify that this difference was more pronounced in areas under no-tillage and conventional tillage when compared to the area under forest.

\section{CONCLUSIONS}

The method which provided greater accuracy was the percentile method. The tomographic image analysis allowed discriminate the porosity of the soil under different soil management conditions. The results approached the real, where the scale used has reference to soil macroporosity, however, other processes occur at the nanometer scale which was not observed in this study.

The soil management changed the soil porosity, and this difference was more pronounced in areas under no-tillage and conventional tillage when compared to the area under forest.

\section{ACKNWOLEGMENTS}

The authors gratefully acknowledge support from Brazilian Agricultural Research Corporation (EMBRAPA), the Coordination of Improvement of Higher Education Personnel (CAPES) and the Studies and Projects Funding Body (FINEP) for financially supporting this research. 


\section{REFERENCES}

BOUMA, J. Measuring the conductivity of soil horizons with continuous macropores. Soil Science Society of America Journal, Madison, v.46, p.438-441, 1982.

CRUVINEL, P. E.; BALOGUN, F. A. Compton scattering tomography for agricultural measurements. Revista Engenharia Agrícola, Jaboticabal, v. 26, n. 1, p. 151-160, 2006.

CRUVINEL, P. E.; PEREIRA, M. F. L. ; SAITO, J H ; COSTA, L F . Performance Improvement of Tomographic Image Reconstruction Based on DSP Processors. IEEE Transactions on Instrumentation and Measurement, New York, v. 58, p. 3295-3304, 2009.

ELLIOT, T.R.; REYNOLDS, W.D.; HECK, R.J. Use of existing pore models and X-ray computed tomography to predict saturated soil hydraulic conductivity. Geoderma, Amsterdam, v.156, n.3-4, p.133-142, 2010.

KUBIENA, W. L. Micromorphological features of soil geography. Brunswick: Rutgers Univ. Press, 1970. 159p.

MATLAB. Version 7.9.0. Matick: The MathsWorks, 2009.

OTSU, N. A Threshold Selection Method from Gray-Level Histograms. IEEE Transactions on Systems, Man, and Cybernetics, New York, v.9, n.1, p. 62-66, 1979.

PAGENKEMPER, S.K.; PETH, S.; PUSCHMANN, D.U.; HORN, R. Effects of Root-Induced Biopores on Pore Space Architecture Investigated with Industrial X-Ray Computed Tomography. In:

ANDERSON, S.H.; HOPMANS, J.W. Soil-Water-Root processes: Advances in Tomography and Imaging. Madison: Soil Science Society of America, 2013, p.69-96. (SSSA Special Publication, 61)

PAPADOPOULOS, A.; BIRD, N.R.A. ; WHITMORE, A.P.; MOONEY, S.J. Investigating the eff ects of organic and conventional management on soil aggregate stability using X-ray computed tomography. European Journal of Soil Science, Oxford, v.60, p.360-368, 2009.

PERRET, J.; PRASHER, S. O.; KANTZAS, A.; LANGFORD, C. A two-domain approach using CAT scanning to model solute transport in soil. Journal Environmental Quality, Madison, v.29, n.3, p.9951010, 2000.

PETH, S.; HORN, R.; BECKMANN, F.; DONATH, T.; FISCHER, J.; SMUCKER, A.J.M. Three dimensional quantification of intra-aggregate pore-space features using synchrotronradiation-based microtomography. Soil Science Society of America Journal, Madison, v.72, n.4, p.897-907, 2008.

PIRES, L. F.; BORGES, J. A. R.; BACCHI, O. O. S.; REICHARDT, K. Twenty-five years of computed tomography in soil physics: A literature review of the Brazilian contribution. Soil and Tillage Research, Amsterdam, v. 110, n. 2, p. 197-210, 2010.

TAINA, I.A.; HECK, R.J.; ELLIOT, T.R. Application of X-ray computed tomography to soil science: A literature review. Canadian Journal Soil Science, Ottawa, v.88, n.1, p.1-20, 2008.

TAVARES FILHO, J.; BARBOSA, G. M. C.; RIBON, A. A. Physical properties of dystrophic Red Latosol (Oxisol) under different agricultural uses. Revista Brasileira de Ciência do Solo, Viçosa, MG, v.34, n.3, 2010.

UDAWATTA, R.P.; GANTZER, C.J.; ANDERSON, S.H.; GARRETT, H.E. Agroforestry and grass buffer effects on high resolution X-ray CT-measured pore characteristics. Soil Science Society of America Journal, Madison, v.72, p.295-304, 2008.

VAZ, C.M.P.; DE MARIA, I.C.; LASSO, P.O.; TULLER. M. Evaluation of an advanced benchtop micro-computed tomography system for quantifying porosities and pore-size distributions of two brazilian oxisols. Soil Science Society of America Journal, Madison, v.75, n.3, p.832-841, 2011.

WANG, W.; KRAVCHENKO, A. N.; SMUCKER, A. J. M.; LIANG, W.; RIVERS, M. L. Intraaggregate Pore Characteristics: X-ray Computed Microtomography Analysis. Soil Science Society of America Journal, Madison, v.76, p. 1159-1171, 2012. 